\title{
Ethanolic Extract of Secang (Caesalpinia sappan L.) Wood Performs as Chemosensitizing Agent Through Apoptotic Induction on Breast Cancer MCF-7 Cells
}

\author{
Rahmi Khamsita ${ }^{1}$, Adam Hermawan ${ }^{2}$, Dyaningtyas Dewi Pamungkas Putri', \\ Edy Meiyanto $^{2 *}$
${ }^{1}$ Cancer Chemoprevention Research Center Faculty of Pharmacy, Universitas Gadjah Mada, Jalan Sekip Utara 555281 (Phone. 02746492662 Fax. 543120) http://ccrc.farmasi.ugm.ac.id
${ }^{2}$ Department of Pharmaceutical Chemistry, Faculty of Pharmacy, Universitas Gadjah Mada \\ Jalan Sekip Utara, Yogyakarta 555281, Indonesia.
}

\begin{abstract}
Resistance to chemotherapy is believed to cause treatment failure of the patient cancer. Secang (Caesalpinia sappan L.) has been proven to possess anticancer activity on some cancer cell lines. The aimed of this study to develop ethanolic extract of secang wood (EES) as chemosensitizing agent through apoptotic induction on breast cancer MCF-7 cells. Extraction of secang was done by using maceration with $70 \%$ ethanol. Single and combinatorial treatment of EES and doxorubicin on MCF-7 breast cancer cells were analyzed by using MTT assay to determine the $\mathrm{IC}_{50}$ value and combination index $(\mathrm{Cl})$ to evaluate the combinatorial effect. Apoptosis was analyzed with flowcytometry (annexin V). EES showed a dose-dependent cytotoxicity $\left(\mathrm{IC}_{50}\right.$ value of $\left.37 \mu \mathrm{g} / \mathrm{ml}\right)$, while combinatorial treatment showed that 7 concentrations was found to be synergist with doxorubicin on MCF-7 cells. Combinatorial treatment also triggered apoptotic instead of single treatment. Based on this result, we conclude that ethanolic extract of secang wood is potential as chemosensitizing agent in breast cancer.
\end{abstract}

Keywords: Caesalpinia sappan L, MCF-7 cells, doxorubicin, apoptosis.

\section{INTRODUCTION}

Doxorubicin is one of the primary chemotherapeutic agents for breast cancer treatment. Medical report by Rumah Sakit Kanker Dharmais stated that in 2007 breast cancer shows the highest incidence compared to another cancer types (Anonymous, 2009). The main problem of clinical systemic chemotherapy are its toxicity towards normal tissues and suppression of the immune system (Wattanapitayakul et al., 2005), and occurrence of resistance (Mechetner et al., 1998). Resistance to chemotherapy is believed to cause treatment failure of the patient. One promising approach to solve this problem is the application of chemosensitizing agent in cancer therapy.

Potent agent which can be used as chemosensitizing agent together with doxorubicin are phytochemical substances, rendering to the fact that there are huge number of substances found in plants that are potential against cancer (Gibbs, 2000), such as homoisoflavonoid namely brazilin, brazilien, 4O-methylsappanol, protosappanin A, and caesalpin $\mathbf{J}$ which found in secang wood (Lim et al.,1997). It was suspected to have anticancer effect. Therefore, further study on its potential as co-chemotherapeutic agent needs to be conducted.

This study aimed to observe cytotoxic effect of ethanolic extract of secang wood (EES) single or in combination with doxorubicin, analyzed by using MTT assay. Combinatorial treatment of EES and doxorubicin were applied in order to increase the cytotoxicity of doxorubicin on MCF-7 cells, allowing the use of lower dose of the chemotherapeutic agent giving less toxicity on normal tissues.

\footnotetext{
*Corresponding author e-mail : meiyan_e@ugm.ac.id
} 


\section{MATERIALS AND METHODS}

\section{Extraction}

Secang woods were collected from Yogyakarta, Indonesia which then determined Department of Pharmaceutical Biology, Faculty of Pharmacy UGM. Dried powder was then extracted by maceration for 5 days with $70 \%$ ethanol. Collected filtrate was concentrated using rotary evaporator (Heidolph WB2000).

\section{Cell culture}

MCF-7 cells are collection of Cancer Chemoprevention Research Center (CCRC), Faculty of Pharmacy, Universitas Gadjah Mada, Yogyakarta, Indonesia. The cell was a gift from Prof. Kawaichi, Nara Institute of Science and Technology (NAIST), Japan. Dulbecco's Modified Eagle Medium (DMEM) powder (Gibco) containing 10\%v/v Fetal Bovine Serum (FBS) (Gibco), and 10,000 units/ml Penicillin$10,000 \mu \mathrm{g} / \mathrm{ml}$ Streptomycin (Gibco) were used for culture medium. Cells were prepared using $0.25 \%$ Tripsin EDTA (Gibco).

\section{Cytotoxicity assay}

MTT cytotoxicity assay was used to examine the effect of ethanolic extract of secang wood on MCF 7 cells, either single or in combination with doxorubicin. Cells were distributed to 96-well plate (Nunc) with the density of $5 \times 10^{3}$ cells/well and incubated in $37^{\circ} \mathrm{C}$ with $5 \% \mathrm{CO}_{2}$ for 24 hours. For the cytotoxicity assay of ethanolic extract of secang wood, a serial concentration of ethanolic extract of secang wood was diluted on DMEM with DMSO (Sigma) as co-solvent, to get $\mathrm{IC}_{50}$ value. In combinatorial assay, concentration of about $1 / 12,1 / 8,1 / 4$, and $3 / 8 \mathrm{IC}_{50}$ were used for both EES and doxorubicin. After 24 hours incubation, 3-[4,5-dimethyl thiazole-2-yl(-2,5- diphenyltetrazoliumbromide)] (MTT) (Sigma) was added, followed by 4 hours incubation. Then $10 \% \mathrm{v} / \mathrm{v}$ SDS in $0.1 \mathrm{~N} \mathrm{HCl}$ (Merck) as stopper reagent was added. Plate was then kept with protection from light overnight, continued with absorbance measurement ( $\lambda 595 \mathrm{~nm})$ using ELISA reader (Bio-Rad). $\mathrm{IC}_{50}$ value, a concentration which inhibits $50 \%$ cell population, was calculated from linear regression of $\log$ concentration versus cells viability.

\section{Apoptotic Induction}

Cells $\left(5 \times 10^{4}\right.$ cells/well $)$ were transfered to 6-well plate (Iwaki) and incubated for 24 hours $\left(37^{\circ} \mathrm{C} 5 \% \mathrm{CO}_{2}\right.$ condition). Cells were treated by EES, doxorubicin, and their combination, and then incubated for 15 hours. Then, cells were centrifugated and added by 100 annexin V-FITC which was diluted in binding buffer. Cells were incubated for 15 minutes and analyzed with flowcytometry $\lambda$ $488 \mathrm{~nm}$.

\section{Analysis}

Combinatorial Assay. Combinatorial treatment was evaluated by calculating Combination Index (CI) value (Reynolds and Maurer, 2005), which has the formula as follows.

$$
C I=\frac{D_{1}}{D_{x 1}}+\frac{D_{2}}{D_{x 2}}+\frac{D_{1} \cdot D_{2}}{D_{x 1} \cdot D_{x 2}}
$$

$\mathrm{D}_{1}$ and $\mathrm{D}_{2}$ represent concentrations used in combinatorial treatment, while $\mathrm{D}_{\mathrm{x} 1}$ and $\mathrm{D}_{\mathrm{x} 2}$ are single treatment concentration giving the same response as $D_{1}$ and $D_{2}$, respectively. CI value acquired will allow the evaluation of EES's potency in combinatorial treatment with doxorubicin on MCF-7 cell lines. Interpretation was done based on the classification listed in Table I.

Table I. Interpretation of CI Values

\begin{tabular}{cc}
\hline $\mathbf{C l}$ & Interpretation \\
\hline$<0.1$ & Very strong synergistic effect \\
$0.1-03$ & Strong synergistic effect \\
$0.3-0.7$ & Synergistic effect \\
$0.7-0.9$ & Moderate synergistic effect \\
$0.9-1.1$ & Nearly additive effect \\
$1.1-1.45$ & Moderate antagonist effect \\
$1.45-3.3$ & Antagonist effect \\
$>3.3$ & Very strong antagonist effect \\
\hline
\end{tabular}




\section{RESULTS AND DISCUSSION}

In this study we explored the effect of EES single and in combination with doxorubicin on cytotoxicity, and apoptotic induction of MCF-7 breast cancer cells. Secang (Caesalpinia sappan L.) had been proved to have cytotoxic and antiproliferative effect against several cancer cell lines such as HepG2, MDA-MB-231 dan MCF-7, A549 cells (Yen et al., 2010). Our study showed that single treatment of EES show cytotoxic effect on MCF-7 with $\mathrm{IC}_{50} 37 \mu \mathrm{g} / \mathrm{ml}$ (Fig. 1). According to Ueda et al. (2000), $\mathrm{IC}_{50}$ value less than 100 $\mu \mathrm{g} / \mathrm{ml}$ shows that related agent has a potent cytotoxicity. Observation of cell morphology after treatment was also done, shown in Fig. 2 and 3. Increasing concentration of EES was followed by the increasing number of dead cells, quantitatively (Fig. 1).

Previous study showed that doxorubicin showed strong cytotoxic effect on MCF-7 breast cancer cell lines with $\mathrm{IC}_{50}$ value $400 \mu \mathrm{M}$ (Hermawan et al., 2010). This is due to the characteristic of MCF-7 which is resistant to doxorubicin by overexpressing anti-apoptotic protein Bcl-2 and P-glycoprotein efflux pump (Davis et al., 2003). To increase the sensitivity of MCF-7 cells towards doxorubicin, we combined doxorubicin with EES.

Our results showed that 7 combinatorial concentration EES and doxorubicin gave synergistic which had CI under 0.9 (Reynolds and Maurer, 2005 (Table II). Combination of EES and doxorubicin (18 $\mu \mathrm{g} / \mathrm{ml}-25 \quad \mathrm{nM})$ showed higher inhibition of proliferation than single treatment in MCF-7 cells (Fig. 2(A)). Observation of cell morphology after treatment was also done, shown in Fig. 2(B-E). This result suggested that this combination give synergistic effect on MCF-7 cells. This synergistic effect is occured due to apoptotic induction and/or cell cycle modulation.

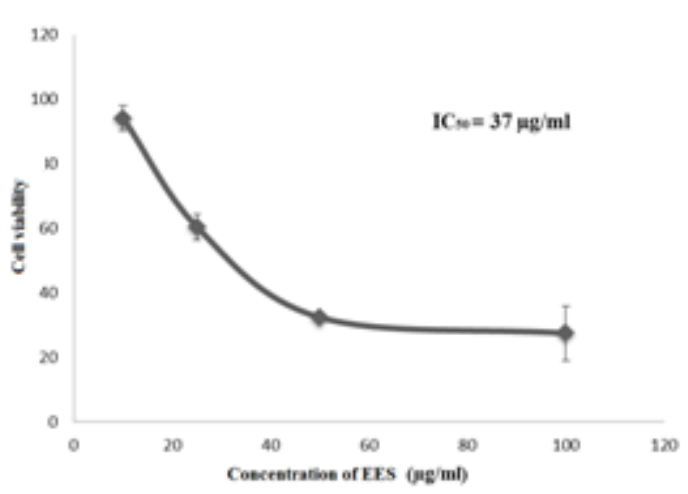

(A)

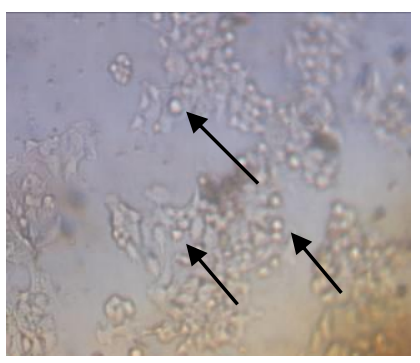

(D)

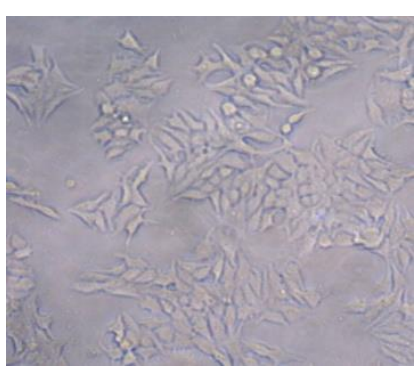

(B)

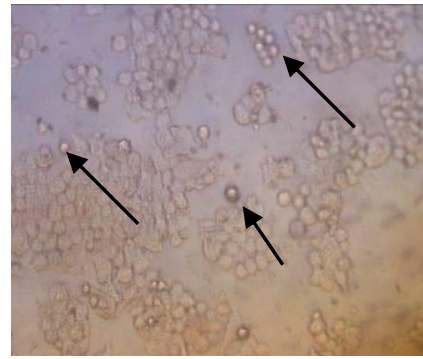

(E)

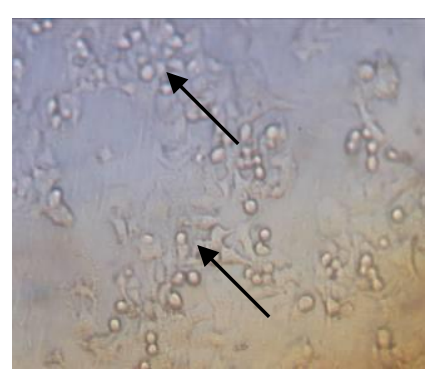

(C)

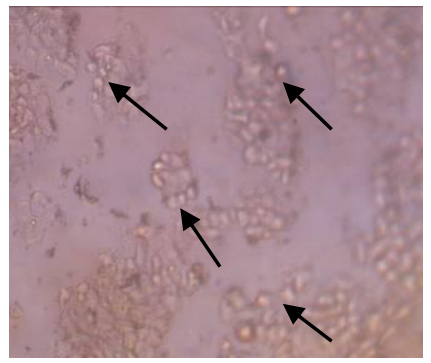

(F)

Figure I. Cytotoxic effect of single treatment EES on MCF-7 cells. Cells were cultured in 96 well plate then treated with EES for 24h (A) The effect of EES to the viability of MCF-7 cells; (B) cell control; (C) $10 \mu \mathrm{gg} / \mathrm{ml}$; (D) $25 \mu \mathrm{g} / \mathrm{ml}$; (E) $50 \mu \mathrm{g} / \mathrm{ml}$; (F) $100 \mu \mathrm{g} / \mathrm{ml}$. Higher concentration of EES caused more change in cells' morphology (round cells being unattached to the well). This phenomenon represents a dose-dependent manner. EES's cytotoxicity was represented as percentage of MCF-7 cells' viability as the mean \pm SD of three experiments, $\mathrm{p}<0.05$. 


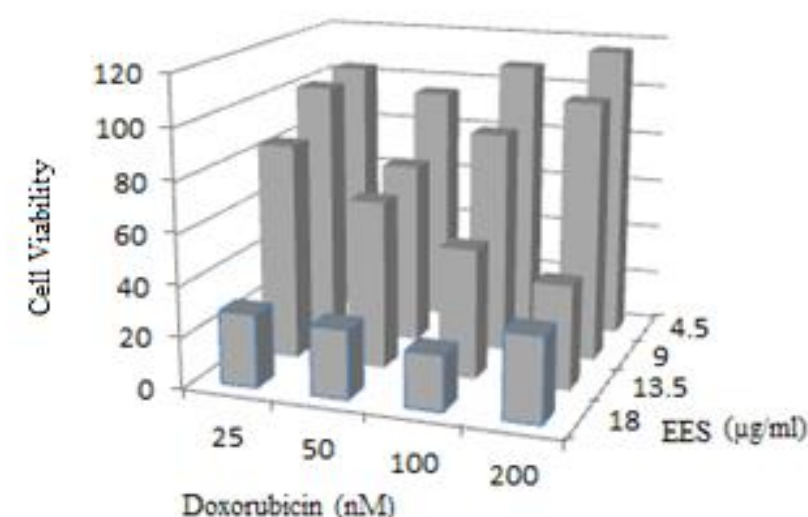

(A)

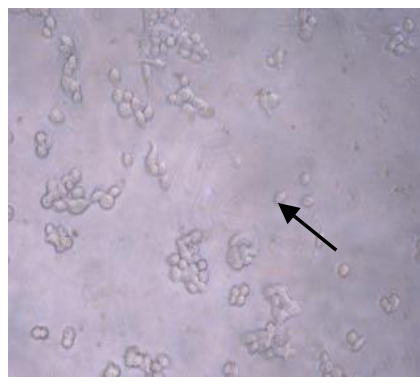

(C)

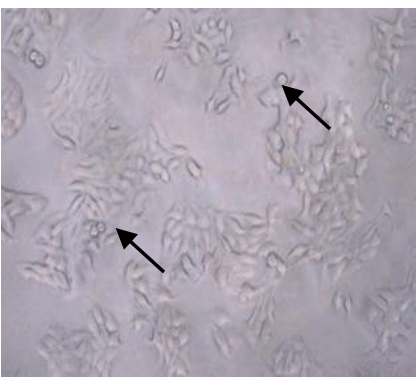

(D)

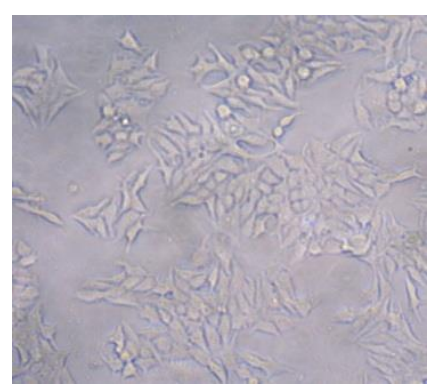

(B)

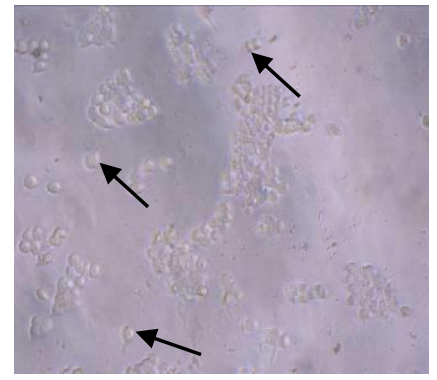

(E)

Figure 2. Cytotoxic effects of combinatorial treatment EES and doxorubicin on MCF-7 cells. Cells were cultured in 96 well plate then treated with EES, Doxorubicin, and the combination for 24h (A) The effect of EES to the viability of MCF-7 cells; (B) cell control; (C) EES 18 $\mu \mathrm{g} / \mathrm{ml}$; (D) doxorubicin $25 \mathrm{nM}$; (E) $18 \mu \mathrm{g} / \mathrm{ml}-.25 \mathrm{nM}$. Combinatorial concentration of EES caused more change in cells' morphology (rounded and deattached cells)

Table II. CI values of combinational treatment of EES and doxorubicinon MCF-7 cells.

\begin{tabular}{ccccc}
\hline EES $(\boldsymbol{\mu g} / \mathbf{m l})$ & \multicolumn{5}{c}{ Doxorubicin (nM) } \\
\cline { 2 - 5 } & $\mathbf{2 5}$ & $\mathbf{5 0}$ & $\mathbf{1 0 0}$ & $\mathbf{2 0 0}$ \\
\hline $\mathbf{4 , 5}$ & 1,29 & 1,36 & 3,36 \\
$\mathbf{9}$ & 1,77 & 0,90 & 2,41 & 7,60 \\
$\mathbf{1 3 , 5}$ & 1,59 & 0,98 & 0,78 & 0,83 \\
$\mathbf{1 8}$ & 0,29 & 0,32 & 0,34 & 0,74 \\
\hline
\end{tabular}

We next investigated whether the EES induced apoptosis on MCF-7 cells. The results from cytotoxic assay of EES and doxorubicin were parallel with apoptotic assay using flowcytometry-annexin V-FITC. Combinatorial treatment increased the death cells caused by apoptosis (Fig.3). Single treatment of EES showed cytotoxic effect and the combination with doxorubicin increased cytotoxicity of doxorubicin in MCF-7 cells. Single treatment of EES did not induce apoptotic, but the combination with doxorubicin increased apoptosis induction of doxorubicin in MCF-7 cells. This result indicated that synergist effect of EES and doxorubicin was through apoptotic induction.
The increased cytotoxic of doxorubicin by EES probably due to up-regulation of p53 and inhibition of Bcl-2. Doxorubicin induces DNA damage and triggers the apoptotic pathway or DNA repair depend on the degree of DNA. In the cells with wild type p53 e.g. MCF-7 cells, upregulation of p53 could increase apoptosis induction or G2/M arrest. Previous study mentioned chloroform extract of secang induced expression of p53 on HNSCC 31 cells and HNSCC4 cells (head and neck cancer cell line) (Kim et al., 2005). Other study mentioned that brazilein as active compound of secang induced apoptotic through modulated Bcl-2 and survivin in HepG2 cells (Zhong et al., 2009). Our results is similar to 
the previous study, but the mechanism need to

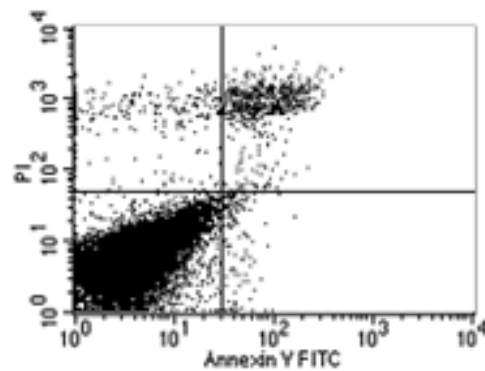

(A)

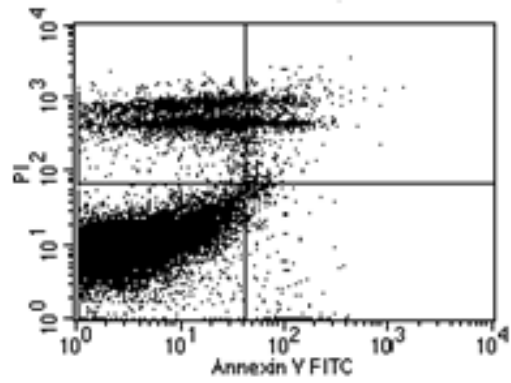

(C) be explored more details in MCF-7 cells.

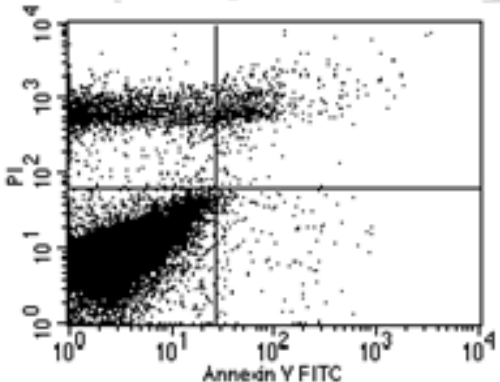

(B)

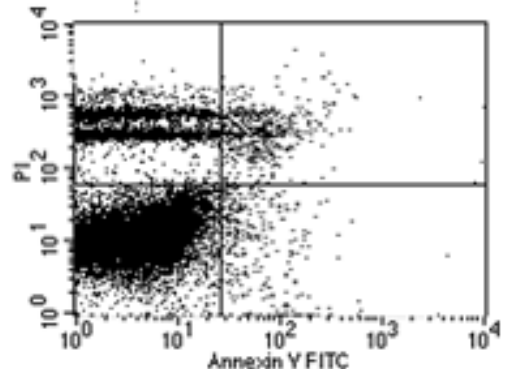

(D)

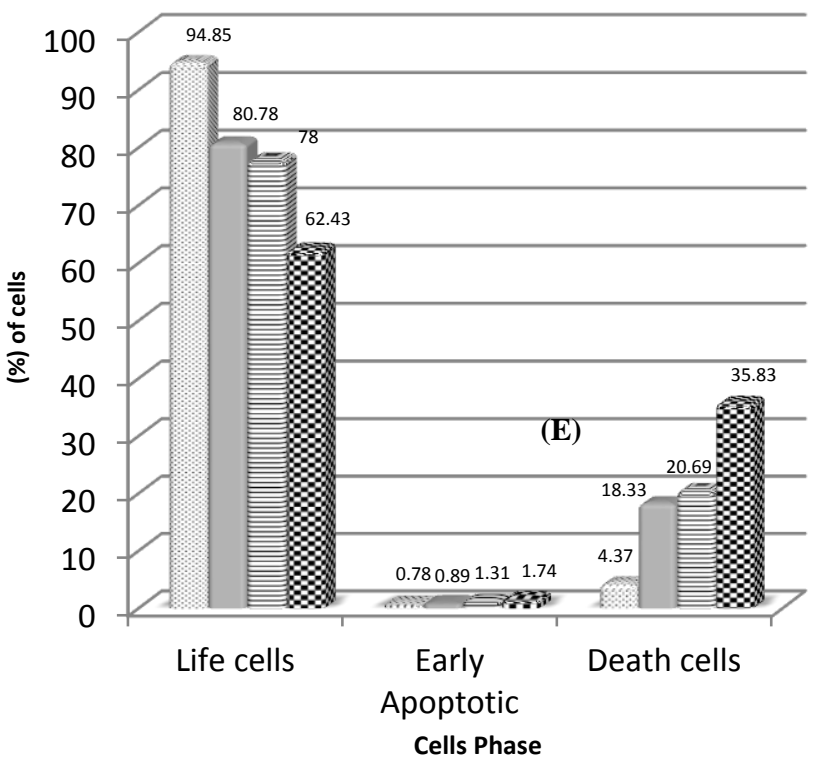

DMSO Control

$\square \mathrm{EES}$

目Doxorubicn

a Combination

Figure 3. The effect of EES and doxorubicin on MCF-7 cells apoptosis. Cells $\left(5 \times 10^{4}\right)$ were treated with EES, doxorubicin, combination, and then incubated for 15 hours. Viable and dead cells were observed with flowcytometry method. (A) control; (B) EES $18 \mathrm{\mu g} / \mathrm{ml}$; (C) doxorubicin 200nM; (D) EES-doxorubicin (18 $\mathrm{\mu g} / \mathrm{ml}-200 \mathrm{nM}$; (E) Graph represent the number of cells each phase.

\section{ACKNOWLEDGEMENT}

We acknowledge

Cancer Chemoprevention Research Center which has funded this research.

\section{REFERENCES}

Anonymous, 2009, Rumah Sakit Kanker Dharmais' Medical Report; Statistik Kanker: 10 Besar Kanker Tersering RSKD Rawat Jalan (Kasus Baru) tahun 2007, available in http://www.dharmais.co.id/index.php/can 
cer-statistic.html, accessed on March 2010.

Davis, J.M., Navolonic, P.M., Weinstein, C.R., Steelman, L.S., Hu, Konovlepa, M., Blagosklonny M.V. and McCubrey, J.A., 2003, Raf-I and Bcl-2 Induce Distinct dan Commn Pathway That Contribute to Cancer Drug Resistance, Clin. Cancer Res., 9, II6I-II70.

Gibbs, J.B., 2000, Anticancer Drug Targets: Growth Factor and Growth Factor Signaling, J. Clin. Inves., I05(I), 9-13.

Hermawan, A., Meiyanto, E. and Susidarti, A., 2010, Hesperidin Meningkatkan Aktivitas Sitotoksik Doxorubicin pada Sel MCF-7, Indonesian J. of Pharm., 2I (I), 8-I7.

Kim, E.C., Hwang, Y.S. and Lee, H.J., 2005, Caesalpinia sappan induces cell death by increasing the expression of $\mathrm{p} 53$ and P2IWAFI/CIPI in head and neck cancer cells, Am. J. Chin. Med., 33, 405-I4.

Lim, D.K., Choi, U. and Shin, D.H., 1997, Antioxidative activity of some solvent extract from Caesalpinia sappan Linn., Korean J. Food Sci. Technol., 28(I), 77-82

Mechetner, E., Kyshtoobayeva, A., Zonis, S., Kim, H., Stroup, R., Garcia, R., Parker, R.J. and Fruehauf, J.P., 1998, Levels of Multidrug Resistance (MDRI) PGlycoprotein Expression by Human Breast Cancer Correlate with in vitro Resistance to Taxol and Doxorubicin, Clin. Cancer Res., 4, 389-398.
Reynolds, C.P. and Maurer, B.J., 2005, Evaluating Response to Antineoplastic Drug Combinations in Tissue Culture Models, Methods in Molecular Medicine, I 10, 173-183.

Ueda, J.Y., Tezuka, Y., Banskota, A.H., Tran, Q.L., Tran, Q.K., Harimaya, Y., Saiki, I, and Kadota, S., 2002, Antiproliferative Activity of Vietnamese Medicinal Plants, Biol. Pharm. Bull, 25(6), 753-760.

Wattanapitayakul, S.K., Chularojmontri, L., Herunsalee, A., Charuchongkolwongse, S., Niumsakul, S. and Bauer, J.A., 2005, Screening of Antioxidants from Medicinal Plants for Cardioprotective Effect against Doxorubicin Toxicity, Basic and Clin. Pharmacol. and Toxicol., 96(I), 80-87.

Yen, C., Nakagawa-Goto, K., Hwang, T.-L., Wu, P.-C., Morris-Natschke, S.L., Lai, W.-C., Bastow, K.F., Changb, F.-R., Wu, Y.-C. and Lee, K.-H., 20I0, Antitumor Agents. 27I. Total Synthesis and Evaluation of Brazilein and Analogs as Anti-inflammatory and Cytotoxic Agents, Bioorg Med Chem Lett, 20(3), 1037-1039.

Zhong, X., Wu, B., Pan, Y.J. and Zheng, S., 2009, Brazilein Inhibits Survivin Protein and mRNA Expression and Induces Apoptosis in Hepatocellular Carcinoma HepG2 Cells, Neoplasma, 56(5). 